\title{
SKILLS AND SCHEMES: THE TRAINING RESPONSE TO YOUTH UNEMPLOYMENT 1
}

\author{
Jane Higgins \\ University of Canterbury
}

\begin{abstract}
The introduction of the Access training scheme in 1987 was a significant point in the history of active labour market policy inNew Zealand and represented a shift away from work schemes to an almost exclusive focus on the provision of training. This shift suggests a changed interpretation of the causes of unemployment and the accompanying official discourse reflects this, referring to skill deficits and mismatches forming rigidities in the labour market and leading to unemployment. This paper investigates the adequacy of this skill discourse (which remains current) and asks whether the provision of schemes such as Access is consistent with the discourse, and is an appropriate policy response to the problem of youth unemployment. The paper adopts a case study approach, analysing the changing structure of employment in the Christchurch youth labour market over the period 1976-1991.
\end{abstract}

Since 1987 active labour market policy in New Zealand has focussed primarily on the provision of training in work and 'life' skills. That year saw the phasing out of the last but one of the employment schemes that had formed the basis of active labour market policy for more than a decade, ending thereby a complicated history of scheme development in which extensions, mixes and mergers grew increasingly convoluted as the years and the unemployment rate advanced.

The move from wage subsidy to training assistance signalled an important shift in labour market policy and in the discourse surrounding that policy. The change suggests an altered perception of the nature of unemployment in New Zealand. Prompted by the persistence of the unemployment problem, by the supply side economics of the Treasury and the fourth Labour government, and by policy trends overseas ${ }^{2}$, policy makers argued that persistent high unemployment was associated with structural change, specifically with the development of barriers to employment through the failure of human capital to adapt to changed employment conditions. The official discourse reflects this shift. Workers with outdated and inappropriate skills, it was argued, were producing skill mismatches leading to unemployment and labour market rigidities. Expressions of this skill discourse can be found throughout official publications of that time. Introducing the transition to Access training the Minister of Employment wrote:

...the Government has sought to achieve a more active approach to training and employment; increasing the emphasis towards accessible training and skill acquisition... [These] measures will ... contribute both to the alleviation of unemployment and to equipping the workforce with the skills and adaptability needed to promote further economic and employment growth (New Zealand Government 1985:4).

The Department of Labour took up this theme:

It was ... apparent to the Govemment that New Zealand's employment problem was not solely a lack of jobs but also ... a mismatch between those skills possessed by the people seeking jobs and those required by the jobs available (LEG September 1986:21).

On the question of the sort of labour force required for the alleviation of unemployment, the discourse was clear:

[A] top priority ... [is] the need for a more flexible workforce with adaptable and transferable skills. Many ... experts have written of the urgency of providing a skilled, creative and adaptable workforce at all levels. A better educated and trained workforce is more employable and better able to transfer skills learnt in one occupation to another. ... Occupational flexibility will become increasingly important in future as the rate of change - in technology and in the needs of industrial nations - is likely to speed up rather than decrease (New Zealand Government 1987:13).

Several important themes of the post-Fordist and flexible specialisation literature are rehearsed in this literature: the transformation of the workplace under the influence of new technology; the growth of niche markets requiring the production of small batch, high quality goods; the shift 
away from Taylorist work practices; the move from adversarial to co-operative labour-management relationships; and, as an integral element of these changes, the need for a "flexible workforce" (cf. Planning Council documents such as Haines 1988, Callister 1990, Rose 1990).

In line with the optimistic tone of the discourse, this is the language not of numerical or wage flexibility but of functional flexibility, calling for an upgrading of skill levels and the development of a multiskilled workforce.

This paper will argue, on both theoretical and empirical grounds, that, as a basis for policy design, this discourse is inadequate.

\section{The skills discourse}

At its heart this discourse posits a simple positive correlation between skill requirements and technological development. It assumes an economy in which skill requirements are rising continually and the workforce is struggling to keep up. Despite the distinctly equivocal nature of the evidence these perceptions persist and have achieved the status of orthodoxy among policy advisors both in New Zealand and overseas. In this section I will suggest why this approach has shown such endurance despite much evidence against it. The methodological issues arising from this discussion will provide a more cogent basis from which to investigate the relationship between skill and technology.

This skill discourse, in which rising skill requirements and increasing technological development are linked in so straightforward a manner, is not unique to policy advice circles of the 1980 s and ' 90 s. It has an enduring record stretching back to the post-industrial society theorists of the 1960 s (Kerr et al. 1960, Clark 1962, Galbraith 1969, Bell 1973) and encompasses some of the flexible specialisation literature of more recent times (Piore and Sabel 1984, Katz and Sabel 1985, cf. Smith 1989). Those who have eschewed this simplicity, notably the industrial sociologists of the 1940 s and ' $50 \mathrm{~s}$, and those of the postBraverman era involved in the labour process and labour market segmentation literatures, have identified more complex relationships prevailing between skill and technology. What the work of these groups shares, and what is omitted by exponents of the skill discourse under discussion, is acknowledgement of the importance the network of historically specific social relationships within which the operation of skill and technology are embedded. This provides a clue to the problem of how this discourse has arisen and why it endures.

At issue is more than the importance of attention to empirical detail. The issue concerns, rather, the ideological nature of the discourse. The practice of skill by workers and the adoption and use of technology by employers are conceptualised in this in such a way that technology possesses an evolutionary logic, according to which it is always becoming more sophisticated, more pervasive; and skill (in accordance with human capital theory) is perceived as a set of technical competencies in which individuals choose to invest in order to enhance their potential productivity, and so maximise their retums in the workforce.

As any glance at labour process or labour market segmentation literature will reveal, these concepts of skill and technology are ill drawn, for they describe forces that are independent of the real practice of workers and employers and innocent of social construction. The processes of calculation, negotiation and struggle among those involved in production which in fact shape the adoption and utilisation of technology and the construction of, and access to, skilled work and skill labels are not only absent here but are unlooked for as well. What is important here is the manner in which the concepts of skill and technology have been formulated. It is my contention, argued briefly below, that adherents of this discourse have formulated these concepts by abstracting them, not from the particular social relations within which skill and technology are actually embedded, but from their apparent independence from these very social relationships.

This is what makes this discourse ideological ${ }^{3}:$ a failure to recognise that, within a capitalist economy, the adoption and use of technology together with the practice of skill bear no clear mark of their origins and formation in the definite social relationships of the capitalist mode of production. I have detailed this argument at length elsewhere (Higgins 1993). Suffice it to say that without an accurate understanding of the way in which the practice of skill and use of technology are generated within these relationships the discourse fails to critique these forms, presenting them instead as independent forces driving the practice of those involved in production.

Indeed, insofar as actors appear in this discourse at all they appear only as bearers of these otherwise independent forces. That is to say, the wielders of skill and technology are conceptualised as the bearers of technical competencies on the one hand, and, on the other, as the means by which the latest technology is adopted and technically competent labour recruited. These are workers and employers of textbook rationality: they follow the laws of human capital theory and they adopt the latest and most appropriate technology for their workplaces using it in the most efficient manner. In other words, they are ideal individuals: like the skills and technology they wield, they are, therefore, misleading abstractions for any real historical analysis.

That misleading abstractions are a feature of this discourse, has been noted by others: Moore $(1987,1990)$ argues that it is the ideology of the free market, not the reality of economic life that constitutes the real context of the discourse of the new vocationalism; Gleeson (1990) argues that training schemes offer a "world of work" which is really an idealised conception of how industrial relations ought to operate and how people ought to behave under 
free market conditions; Cutler (1992) argues that the model of British manufacturing firms used in the rhetoric surrounding "the British training problem" assumes, "a productively virtuous enterprise" that realises profit only through manufacture and never through acquisition, merger, tight control of costs and use of assets.

These abstractions fail to grasp the historical realities of "the world of work", industrial relations, the productive enterprise, as well as skill construction, technological utilisation and so forth because their authors fail to anchor their analysis in the social relations specific to capitalism.

Identifying the real structure of capitalist relationships, among workers, among employers, between these groups, and among these groups and the state, makes possible the reconceptualisation of skill and technology. This is because it is from the basis of these specific relationships that people act to define skilled work, to circumscribe access to it, to shape decisions about the adoption and use of technology, and so on. It is this practice that must be the subject of analysis.

Such analysis recalls the literature of labour market segmentation and the labour process. The former proposes a break in "the assumed direct link between the structure of jobs and skills and the distribution of the productivities and abilities of the population" (Burchell and Rubery 1990). The latter, likewise, proposes a break in the assumed direct link between the technical competency of tasks and the skill labels attached to them. Incorporated in these discontinuities is a network of social relationships that structure the labour process and the labour market through activities such as employer recruitment practices (Windolf and Wood 1988, Ashton and Maguire 1980, 1981), workers' strategies of occupational closure and control (Penn 1985, Bradley 1986, Witz 1986), the social construction of skill (Hill and Gidlow 1988, Steiger 1993) and so forth.

Now, if the key concepts of the skill discourse are misleading then its chief propositions regarding skill trends and skill mismatch are in jeopardy, or, at least, are still to be proved.

The question of evidence is an interesting one. The falsely abstract nature of the discourse has encouraged a methodology which is likewise divorced from an analysis of capitalist social relations of production. Ignoring these relationships this method (found, for example, in some Planning Council documents) has focussed on the statistical analysis of sectoral and (less often) specific occupational change at the level of national aggregate data. But this methodology is flawed, not only because it ignores what is happening within the workplace but also because it fails to recognise that relationships of production are structured across space, and the skill trends they generate are likewise structured in space (Massey 1984, Ashton, Maguire and Spilsbury 1990). Any assumption of national homogeneity in skill trends is therefore false. What is required is a methodology based on statistical and other analysis of local labour markets together with case study analysis on the office, shop and factory floor. This will allow the reconceptualisation of skill and technology and assist in the identification of skill trends and their role in the dynamics of unemployment.

Drawing on this method, the following analysis is taken from a larger study of the Christchurch youth labour market. Research was undertaken on two levels involving, first, the analysis of Census data between 1976 and 1991, in order to identify occupational trends, and secondly, case study analysis of the occupations that were most significant for youth. The latter took the form of in-depth interviews with forty-five employers, workers, trainers (both in-firm and at training institutions) and trade unionists as well as the analysis of secondary data such as official publications, newspapers, periodicals, trade directories and so forth. For reasons of space only full time work is considered here.

\section{The Christchurch youth labour market, 1976-1991: occupational trends}

The most notable trend in youth employment in this labour market has been the progressive decline in full time jobs in occupations that, traditionally, have offered young people sheltered ports of entry to work that is regarded as skilled and as offering career opportunities.

Table 1 illustrates the involvement of young men and women in the occupations that were significant $t^{4}$ for them during the period 1976-1991. The table suggests that full time employed young people have been moving out of work in the professions and apprenticeable trades and into the domain of secondary employment.

A skills deficit interpretation of the data is possible: that is, that skill requirements in skilled occupations are rising beyond the abilities of young people seeking this work. But, justification of this interpretation requires, first, attention to the relationships of production within the workplace in order to determine (i) whether skill requirements in these occupations are indeed rising and (ii) who is being employed, if not young people, and why. Secondly, it requires attention to the relationships of production beyond the workplace by way of analysis of the local labour market in its regional, national and global context in order to investigate the changing structure of employment in these occupations and in their relevant industries.

Clearly such analysis is beyond the scope of this paper. It is possible, however, to offer some illustrations of how, in this case, a skills deficit interpretation is inappropriate.

Consider table 2. It suggests that, as far as work formally recognised as skilled is concerned, job losses for the period in question have been considerable in the apprenticeable trades, but much less so for nursing and teaching.

However, table 3 indicates that the concentration ${ }^{5}$ of 
Table 1. Significant youth occupations as a percentage of each full time gender-age cohort, Canterbury urban area 1976-1991

\begin{tabular}{|c|c|c|c|c|}
\hline & 1976 & 1981 & 1986 & 1991* \\
\hline \multicolumn{5}{|l|}{ Females 15-19 years } \\
\hline Medical and related & 10.5 & 7.0 & 0.6 & 0.9 \\
\hline Teaching & 4.4 & 3.3 & 1.6 & 0.3 \\
\hline Dressmaking & 7.8 & 6.8 & 7.6 & $* * *$ \\
\hline Keyboard & 13.1 & 9.3 & 6.8 & 5.8 \\
\hline Numerical clerical & 8.8 & 9.5 & 12.4 & 11.2 \\
\hline General clerical & 18.0 & 19.8 & 22.9 & 20.5 \\
\hline Housekeeping, restaurant & 4.2 & 4.6 & 5.3 & 5.8 \\
\hline Sales & 10.0 & 12.2 & 11.8 & 16.2 \\
\hline \multicolumn{5}{|l|}{ Females 20-24 years } \\
\hline Medical and related & 12.5 & 14.8 & 9.1 & 4.5 \\
\hline Teaching & 10.7 & 7.0 & 3.6 & 3.1 \\
\hline Keyboard & 17.3 & 12.3 & 9.4 & 7.1 \\
\hline Numerical clerical & 8.9 & 10.1 & 10.2 & 14.1 \\
\hline General clerical & 16.7 & 17.0 & 18.5 & 15.9 \\
\hline Sales & 4.9 & 5.6 & 6.3 & 7.8 \\
\hline \multicolumn{5}{|l|}{ Males $15-19$ years } \\
\hline Machine fitting & 10.9 & 11.8 & 8.2 & 4.8 \\
\hline Plumbing and related & 6.4 & 5.3 & 5.3 & 3.3 \\
\hline Electrical & 5.8 & 5.7 & 6.7 & 3.1 \\
\hline Construction & 10.5 & 3.9 & 6.7 & 10.6 \\
\hline General clerical & 5.8 & 5.8 & 6.5 & 10.1 \\
\hline Labouring & 7.0 & 10.8 & 8.4 & 10.0 \\
\hline Sales & 4.1 & 5.4 & 6.0 & 9.7 \\
\hline Material handling & 5.5 & 4.8 & 5.7 & 5.9 \\
\hline Food processing & 5.6 & 5.4 & 5.4 & 6.6 \\
\hline \multicolumn{5}{|l|}{ Males 20-24 years } \\
\hline Machine fitting & 8.8 & 9.1 & 8.6 & 4.0 \\
\hline Plumbing and related & 5.1 & 4.7 & 4.4 & 3.0 \\
\hline Electrical & 5.1 & 5.6 & 4.9 & 3.6 \\
\hline Construction & 7.4 & 5.9 & 4.4 & 9.5 \\
\hline General clerical & 6.4 & 5.6 & 6.1 & 4.1 \\
\hline Labouring & 3.9 & 5.6 & 4.9 & 6.0 \\
\hline Sales & 3.1 & 3.5 & 4.0 & 6.3 \\
\hline
\end{tabular}

Source: Statistics New Zealand, Census of Population and Dwelling

Table 2. All age full time employment: professions and apprenticeable trades

\begin{tabular}{lcccc}
\hline & 1976 & 1981 & 1986 & $1991^{*}$ \\
\hline Females & 2829 & 2901 & 2841 & 2625 \\
Medical and related & 2535 & 2274 & 2112 & 2343 \\
Teaching & & & & \\
Males & 5307 & 3429 & 3807 & 4779 \\
Construction & 5889 & 4941 & 4599 & 2139 \\
Machine fitting & 3042 & 2529 & 2331 & 1332 \\
Plumbing and related & 2823 & 2661 & 2529 & 1488 \\
Electrical & &
\end{tabular}

Source: Statistics New Zealand, Census of Population and Dwellings. 


\section{Table 3. Occupational relative concentration ratios: professions and apprenticeable trades}

\begin{tabular}{lllll}
\hline & 1976 & 1981 & 1986 & $1991^{*}$ \\
\hline $\begin{array}{l}\text { Females 15-19 years } \\
\text { Medical and related }\end{array}$ & 1.23 & 0.79 & 0.07 & 0.12 \\
Teaching & 0.57 & 0.48 & 0.30 & 0.05 \\
Females 20-24 years & & & & \\
Medical and related & 1.47 & 1.67 & 1.23 & 0.63 \\
Teaching & 1.40 & 1.01 & 0.65 & 0.49 \\
Males 15-19 years & & & & \\
Construction & 1.54 & 0.82 & 1.29 & 1.40 \\
Machine fitting & 1.45 & 1.71 & 1.30 & 1.42 \\
Plumbing and related & 1.65 & 1.50 & 1.65 & 1.57 \\
Electrical & 1.60 & 1.55 & 1.92 & 1.32 \\
Males 20-24 years & & & & \\
Construction & 1.09 & 1.24 & 0.85 & 1.26 \\
Machine fitting & 1.17 & 1.33 & 1.37 & 1.18 \\
Plumbing and related & 1.31 & 1.34 & 1.38 & 1.43 \\
Electrical & 1.41 & 1.52 & 1.42 & 1.55 \\
\hline
\end{tabular}

Source: Statistics New Zealand, Census of Population and Dwellings.

Note: This relative concentration ratio (Ashton et al., 1990) has a value greater than 1 if a group is over-represented according to their representation in the general (fulltime employed) population.

A value less than 1 indicates under-representation.

young people relative to older workers in these occupations has declined for young women in nursing and teaching but shows little significant change for young men in the trades.

This suggests that young men have been reasonably successful in competing with those in the next age group to retain employment within a set of occupations seriously affected by job loss. In nursing and teaching, however, although job losses have been much less severe, the younger women have been unable to maintain their former participation rates.

Case studies of these occupations suggest that skill requirements have indeed risen since the 1970s. However, these changes have been readily incorporated into training courses and, at the time of interviewing (1991-92), trainers and employers reported that suitable young applicants outnumbered both the training places and jobs available. In some cases, for example in teaching and engineering, the quality of applicant had encouraged instructors to raise the skill content of their training courses beyond the required level.

In fact, general job loss in the apprenticeable trades has been primarily responsible for the declining involvement of young men in these occupations (table 1). In some cases, as with building and construction, this was the result of the interaction of technological change and macroeconomic relationships: a lot of skilled building labour was shed in the downturn of the late 1970s and not all of this was picked up again during the mid-1980s boom. This was because, in the interim, firms had taken the opportunity to transform their labour process adopting production methods that were less labour intensive of skilled tradespeople than had been the case in the past. The boom provided an environment in which subcontracting, specialisation and prefabrication trends, were accelerated and intensified. In engineering on the other hand, job loss was primarily the result of macroeconomic factors: recovering from the late 1970s downturn, firms became involved in the wave of merger and takeover activity that followed the deregulation of the country's financial markets. Large firms targeted smaller manufacturing concerns encouraging a northward migration, to the larger markets of the North Island, by many head offices and factories. In the later 1980s the removal of import barriers, together with the recession, had a very severe impact on engineering firms in Christchurch.

For young women on the other hand, whose entry into nursing and teaching had been doubly sheltered, both by privileged access to the formal training process and by the traditional exit of women in their twenties and thirties, it was not job loss but the changing nature of women's participation in the labour force that was significant. The decline in access for new entrants, indicated by table 3 , has arisen because women are breaking their employment less than in the past. 
Table 4. Occupational relative concentration ratios: clerical, retail and other

\begin{tabular}{lllll}
\hline & 1976 & 1981 & 1986 & $1991^{*}$ \\
\hline Females 15-19 years & & & & \\
Keyboard & 1.04 & 0.91 & 0.82 & 0.78 \\
Numerical clerical & 1.23 & 1.26 & 1.54 & 1.22 \\
General clerical & 1.18 & 1.22 & 1.39 & 1.60 \\
Sales & 1.30 & 1.70 & 1.94 & 2.47 \\
Dressmaking & 1.06 & 1.08 & 1.36 & $* * *$ \\
Housekeeping, restaurant & 0.82 & 0.98 & 1.10 & 1.31 \\
& & & & \\
Females 20-24 years & 1.37 & 1.21 & 1.14 & 0.95 \\
Keyboard & 1.24 & 1.34 & 1.27 & 1.54 \\
Numerical clerical & 1.09 & 1.05 & 1.12 & 1.25 \\
General clerical & 0.63 & 0.77 & 1.04 & 1.19 \\
Sales & & & & \\
& & & & \\
Males 15-19 years & 1.08 & 1.24 & 1.38 & 2.79 \\
General clerical & 2.42 & 2.71 & 2.77 & 2.66 \\
Labouring & 1.49 & 1.81 & 2.20 & 2.68 \\
Sales & 1.10 & 1.05 & 1.40 & 1.67 \\
Material handling & 1.26 & 1.20 & 1.43 & 2.00 \\
Food processing & & & & \\
Males 20-24 years & 1.18 & 1.19 & 1.28 & 1.12 \\
General clerical & 1.34 & 1.42 & 1.63 & 1.61 \\
Labouring & 1.15 & 1.18 & 1.49 & 1.73 \\
Sales & & & & \\
\hline Source: Stistics & & & & \\
\hline
\end{tabular}

Source: Statistics New Zealand, Census of Population and Dwellings

As opportunities in these skilled occupations have declined young people have shown an increased concentration relative both to the rest of the workforce (table 4) and to their own age cohorts (table 1) in many of their arguably less skilled traditional occupations.

This suggests that, where employment is falling (table 5), young people have been slower to move out of this work than have older workers. Case study work suggests that one of the main reasons for this was the generally rising trend of unemployment during the 1980 s which, together with the increasing participation of women in paid work, placed a lot of experienced labour in the market. This was more attractive to employers than untried and untrained labour, thereby giving workers in the next age group more room to move in the market.

In addition, changes in some of these occupations indicate polarisation occurring within their labour processes, making it more difficult for new entrants to gain a diversity of experience or training that would equip them for other work. The reasons for this polarisation are various and complex, but are associated with the intensification of competition and the availability of new technology offering a combination of speed and task simplification. For example, in both apparel and retail one of the most important influences behind this change was competition from imports following the dismantling of import barriers in the 1980s. This led firms to target their markets with care, choosing to compete in either price or quality, a process that encouraged polarisation in the labour process: in apparel, between piece workers and whole garment workers; and in retail, between the cashier at the cash-and-wrap bar and the sales consultant with a personalised sales approach. Employers reported a preference for older women in the more skilled work, as whole garment workers and sales consultants, and young people as piece workers and cashiers.

Young people in Christchurch have thus experienced diminished access to formally recognised skilled work, and have found few attractive opportunities opening up in other traditional youth occupations.

Table 6 shows that the fall in the full time employment of young people was closely matched by movement into the non-labour force. As well as unemployment this included extended periods in school and considerable movement into further education. Here young people were hampered less by lack of skills than by lack of training places: in 1986 the National Advisory Council on the Transition from School to Working Life reported that more qualified applicants existed for places in both polytechnics and universities than there were training places available. 


\begin{tabular}{|c|c|c|c|c|}
\hline & 1976 & 1981 & 1986 & 1991* \\
\hline \multicolumn{5}{|l|}{ Females $15-19$ years } \\
\hline Keyboard & 957 & 537 & 372 & 162 \\
\hline Numerical clerical & 645 & 549 & 678 & 312 \\
\hline General clerical & 1317 & 1143 & 1257 & 573 \\
\hline Sales & 735 & 708 & 648 & 453 \\
\hline Housekeeping, restaurant & 306 & 264 & 291 & 162 \\
\hline Dressmaking & 570 & 390 & 417 & *** \\
\hline \multicolumn{5}{|l|}{ Females 20-24 years } \\
\hline Keyboard & 1377 & 984 & 801 & 486 \\
\hline Numerical clerical & 708 & 807 & 867 & 963 \\
\hline General clerical & 1329 & 1356 & 1572 & 1092 \\
\hline Sales & 387 & 444 & 537 & 534 \\
\hline Housekeeping, restaurant & 270 & 249 & 417 & 312 \\
\hline Dressmaking & 336 & 345 & 411 & *** \\
\hline \multicolumn{5}{|l|}{ Females All Age } \\
\hline Keyboard & 4176 & 3381 & 3189 & 2724 \\
\hline Numerical clerical & 2379 & 2490 & 3102 & 3339 \\
\hline General clerical & 5052 & 5361 & 6387 & 4683 \\
\hline Sales & 2553 & 2388 & 2349 & 2406 \\
\hline Housekeeping, restaurant & 1686 & 1542 & 1872 & 1623 \\
\hline Dressmaking & 2421 & 2067 & 2160 & *** \\
\hline \multicolumn{5}{|l|}{ Males 15-19 years } \\
\hline General clerical & 444 & 366 & 390 & 321 \\
\hline Labouring & 531 & 678 & 501 & 318 \\
\hline Sales & 309 & 342 & 357 & 309 \\
\hline Material handling & 420 & 303 & 342 & 189 \\
\hline Food processing & 429 & 342 & 324 & 210 \\
\hline \multicolumn{5}{|l|}{ Males 20-24 years } \\
\hline General clerical & 708 & 561 & 603 & 321 \\
\hline Labouring & 429 & 567 & 489 & 477 \\
\hline Sales & 348 & 357 & 402 & 495 \\
\hline Material handling & 468 & 441 & 468 & 315 \\
\hline Food processing & 474 & 459 & 426 & 330 \\
\hline Males All Age & & & & \\
\hline General clerical & 4224 & 3360 & 3450 & 2289 \\
\hline Labouring & 2253 & 2856 & 2205 & 2379 \\
\hline Salespersons & 2127 & 2163 & 1980 & 2292 \\
\hline Material handling & 3927 & 3300 & 2967 & 2247 \\
\hline Food processing & 3492 & 3246 & 2766 & 2091 \\
\hline
\end{tabular}

Source: Census, Christchurch Urban Area

Case study work suggests that this was still true in Christchurch in the early 1990s (Higgins 1993).

\section{A training response?}

If more young people are applying for skilled training and work than there are places available then the skill discourse falls a little flat. It may be argued that the problem lies with youth who are too unskilled to apply for these places and that, therefore, low level training programmes such as Access and TOPS are appropriate policy responses. But let us approach the problem from the perspective of the relations of production.

Low level training programmes will not help young people back into their traditional skilled occupations. They were never in danger of missing out on these jobs through lack of skill, nor indeed on any job which, like these, organised youth entry according to a formal training programme.

This is because the maintenance of formal training paths in skilled occupations such as those discussed here has gen- 


\begin{tabular}{lrrrr}
\hline & $\mathbf{1 9 7 6}$ & $\mathbf{1 9 8 1}$ & $\mathbf{1 9 8 6}$ & 1991 \\
\hline \% Males 15-19 years & & & & \\
Full Time & 50.2 & 44.2 & 42.8 & 24.2 \\
Part Time & 4.4 & 6.4 & 6.4 & 11.0 \\
Not Employed & 45.4 & 49.3 & 50.8 & 64.8 \\
& & & & \\
\% Males 20-24 years & 79.6 & 75.1 & 72.6 & 57.6 \\
Full Time & 2.2 & 2.9 & 3.2 & 4.5 \\
Part Time & 18.2 & 21.9 & 24.2 & 37.8 \\
Not Employed & & & & \\
& 48.6 & 41.1 & 40.0 & 21.2 \\
\% Females 15-19 years & 6.2 & 8.3 & 7.5 & 13.2 \\
Full Time & 45.2 & 50.6 & 52.5 & 65.6 \\
Part Time & & & & \\
Not Employed & & & & \\
\% Females 20-24 years & 60.0 & 60.4 & 62.7 & 51.5 \\
Full Time & 6.4 & 6.6 & 5.9 & 8.7 \\
Part Time & 33.6 & 33.0 & 31.4 & 39.8 \\
Not Employed & & &
\end{tabular}

Source: Census, Christchurch Urban Area

erally been in the interests of both employers and workers. For employers, formally organised training and entry processes offer the obvious technical advantage of ensuring that new entrants are trained in necessary skills and brought up to date with changes in the labour process. For occupational (employee) groups it is critical that new recruits are trained well, by the approved pathways, because the formal recognition of skill is such an important component of bargaining power. In addition, because the struggle by workers to retain formally recognised skills is contested not only with employers but also with other workers, the admission of new entrants into an occupational labour market through formalised training provides the basis for occupational closure and some control over skill definitions.

Traditionally both employee groups and prospective employers have participated in defining and maintaining these training and entry processes in the primary youth occupations, for it has been in the interests of both groups to do so. However, the balance of interests has by no means been static. Throughout the 1970 s and 1980s all the unions associated with these occupations were engaged either defensively or offensively in the protection and expansion of occupational boundaries. For example:

* Teachers sought the formal (and financial) recognition of new skills, as the scope of education broadened. They campaigned for improved training; for a higher degree of closure through the tightening of teacher registration; and for the improvement of pay differentials for qualifications. Successes in the 1970 s, a time of teacher shortage, dwindled in the $1980 \mathrm{~s}$, as shortage turned to surplus, amidst cost cutting and falling rolls.
* The Engineers Union campaigned for formal recognition of the skills and responsibilities involved in new methods of quality assurance. As well, the apprentice training syllabus was expanded to include training in $\mathrm{CNC}$ programming.

* Automotive mechanics, concerned lest they lose the initiative over new electronics developments, ensured that new skills involving the electronic aspects of modem vehicles were incorporated into their apprenticeship programmes.

* Electriciansco-opted electronics skills into their apprenticeship courses rather than allow electronics to develop as a separate subject.

* The local Builders' Union encouraged closure by protecting its apprentices: its awards prohibited youth rates for non-apprenticed labour and encouraged a relatively high rate for unskilled labour on-site in order to discourage substitution of unskilled for skilled workers.

The success of these measures has varied and was always a matter for negotiation between interested groups including employers, workers and various branches of government.

The key point illustrated here is that for many workers and their organisations, training is crucial to the maintenance of skill recognition and occupational closure. In the struggle over skills - to get skills recognised by employers, to keep skills within occupational boundaries, to co-opt new skills - workers have an interest in maintaining high levels of training. For employers, training is important for 
productivity although the level of training required and the degree of skill recognition is likely to be a matter of contention with workers. Young people are, therefore, unlikely to be disadvantaged by increasing skill requirements within occupations in which training and entry are formally organised and in which there is some balance of control between workers and employers over skill acquisition. A skill deficit may of course arise if not enough people are prepared to undertake training. In a time of high unemployment this is unlikely to happen, and in fact the overabundance of suitable applicants for training places was a constant refrain in the interviews for this study.

In occupations where formal training does not exist and where workers are not powerful enough to achieve much formal skill recognition young people may be disadvantaged by lack of experience and poor access to on-the-job training. For example, in retail, clerical and apparel occupations, which have traditionally employed many young people, the absence of much formal training makes experience attractive to employers. Therefore, when experienced labour is abundant young people are at a disadvantage. In this situation, they are likely to be employed if they are cheaper than experienced labour or if they can be employed in work which requires little on-the-job training. The disadvantage to youth in this situation is that they may become trapped in low skilled work from which it is difficult to move on, as appears to have been happening in the retail and apparel industries in Christchurch.

A low level training programme is unlikely to prevent this from happening. It may shuffle the dole queue around low skilled work, keeping youth in a work ready state as they move into and out of training programmes and employment. It will provide little in the way of higher level skills that will enable them to move on to better jobs. As they are already over-represented in poor work this is not much of a solution to the problem of youth unemployment.

\section{Future research}

A better solution is to anchor policy design in an in-depth investigation of youth unemployment based on real historical analysis, that is, on the specific realities of local labour markets, taking into account the social relationships that shape these realities both in the workplace and across space. An approach based on these relationships opens up an extensive range of research possibilities.

For example, this paper has argued for the importance of a balance of control between employers and workers in maintaining a long term positive perspective on skill development. Research might investigate the role of unions and professional associations in the creation of a skilled workforce. It might explore whether the undermining of these groups through the Employment Contracts Act and professional deregulation will have a long term effect on skills and training in the workforce, particularly in the context of the internationalisation of the New Zealand economy.
More New Zealand research is needed to explore the mechanisms of occupational closure and skill construction exercised by some workers to the exclusion of others particularly in terms of the segmentation of the labour market along the lines of gender and ethnicity.

Research is needed, also, to analyse employer recruitment practices. This includes examining employers' perceptions of skill requirements and their use (and non-use) of job descriptions. As well, informal recruitment channels, such as extended internal labour markets (Windolf and Wood 1988), require investigation. It is also important to identify those features that give employers confidence in training qualifications. To what extent is their own input important, for example, and how important is it that training be specifically relevant to jobs for which they are recruiting? On the basis of United Kingdom research investigating these questions Raffe (1990) argues in favour of giving trainees who are outside informal recruiting networks access to them, and for training in occupationally specific skills that are in demand in the local labour market.

Policy responses to youth unemployment in New Zealand should be based on such concrete analysis. The official skill discourse that currently informs this policy is a culde-sac whose poorly defined abstractions offer, at best, imprecision, but more commonly, entirely misleading directions for policy.

\section{Notes}

1. This paper has been written with the financial support of a New Zealand Federation of University Women fellowship.

2. Australia (Australian Science and Technology Council 1983), the United Kingdom (Manpower Services Commission 1981) and the United States (Task Force on Education for Economic Growth 1983) had, earlier in the decade, made similar moves involving the promotion of skills training to the top of the active labour market policy agenda, to an accompaniment of very similar rhetoric. (See also Burke 1985)

3. Green (1990) makes a similar point about the ideological nature of human capital theory.

4. Occupations termed 'significant' employed $5 \%$ or more of each full time employed gender-age cohort. Note that the 1991 data is asterisked because the census occupational classification changed in 1991. The match has been made as close as possible for this study, but the data are not strictly comparable. The 1991 dressmaking classification could not be made comparable.

5. This relative concentration ratio (Ashton et al., 1990) has a value greater than 1 if a group is over-represented according to their representation in the general (full time employed) population. A value less than 1 indicates underrepresentation. 


\section{References}

Ashton, D. and M. Maguire, 1980 The function of academic and non-academic criteria in employers' selection strategies British Journal of Guidance and Counselling, July, 8(2):146-157.

Ashton, D. and M. Maguire, 1981 Employers perceptions and use of educational qualifications Educational Analysis 3(2):25-36.

Ashton, D., M. Maguire and M. Spilsbury, $1990 R e$ structuring the labour market: the implicationsfor youth Macmillan, London.

Australian Science and Technology Council, 1983 Technical change and employment. Canberra, Australian Government Publishing service.

Bell, D., 1973 The coming of post-industrial society Basic Books, New York.

Bradley, H. 1986 Technological change, management strategies, and the development of gender-based job segregation in the labour process in D. Knights and $\mathrm{H}$. Willmott (eds) Gender and the labour process Gower, Aldershot : 54-73.

Burchell, B. and J. Rubery 1990 An empirical investigation into the segmentation of the labour supply Work Employment and Society 4(4):551-575.

Burke, K. 1985 Labour market assistance measures: a paper from the Minister of Employment Unpublished paper for the Employment Promotion Conference, March 1985.

Callister, P. 1990 Tomorrow's skills New Zealand Planning Council, Wellington.

Clark, B.R. 1962 Educating the expertsociety Chandler, San Francisco.

Cutler, T. 1992 Vocational training and British economic performance: a further instalment of the British Labour Problem? Work Employment and Society 6(2):161-183.

Galbraith, K. 1969 The affluent society 2nd ed. rev. Hamilton, London.

Gleeson, D. 1990 Skills training and its alternatives in D. Gleeson (ed.) Training and its alternatives Open University Press, Milton Keynes 187-199.

Green, F. 1990 The political economy of training reform University of Leicester, Department of Economics Discussion Paper No. 141.

Haines, L. 1988 Our education and training choices: post-compulsory education and training in New Zealand New Zealand Planning Council, Wellington.

Higgins, J. 1993 Beyond the ideology of upskilling: the theory and practice of skill trends analysis Unpublished Ph.D. thesis University of Otago.

Hill, R. and B. Gidlow 1988 From hot metal to cold type: negotiating technological change in the New Zealand newspaper industry Department of Scientific and Industrial Research, Wellington.

Katz, H.C. and C.F. Sabel 1985 Industrial relations and industrial adjustment in the car industry Industrial Relations 24(2):295-315.

Kerr, C., J.T. Dunlop, F.H. Harbison and C.A. Myers 1960 Industrialism and industrial man Oxford University Press, New York.

LEG (various issues) Labour Employment Gazette Department of Labour, Wellington.

Manpower Services Commission 1981 A new training initiative: a consultative document Manpower Services Commission.

Massey, D. 1984 Spatial divisions of labour: social structures and the geography of production Macmillan, London.

Moore, R. 1987 Education and the ideology of production British Journal of Sociology of Education 8(2):227242.

Moore, R. 1990 Knowledge, practice and the construction of skill in D. Gleeson (ed.) Training and its alternatives Open University Press, Milton Keynes 200-212.

NACTSWL 1986 Report on the discussion paper Skills for young people National Advisory Committee on the Transition from School to Working Life, Wellington.

New Zealand Government 1985 A new deal in training and employment opportunities Government Printer, Wellington.

New Zealand Government 1987 Further education and training: who should pay? Govermment Printer, Wellington.

Penn, R. 1985 Skilled workers in the class structure Cambridge University Press, Cambridge.

Piore, M.J. and C.F. Sabel 1984 The second industrial divide Basic Books, Nęw York. 
Raffe, D. 1990 The context of the Youth Training Scheme: an analysis of its strategy and development in D. Gleeson (ed.) Training and its alternatives Open University Press, Milton Keynes 58-75.

Rose, D. 1990 The fully employed high income society New Zealand Planning Council, Wellington.

Smith, C. 1989 Flexible specialisation, automation and mass production Work Employment and Society 3(2):203-220.

Steiger, T.L. 1993 Construction skill and skill construction Work Employment and Society 7(4):535-560.

Task Force on Education for Economic Growth 1983 Action for excellence Education Commission of the States, Denver.

Windolf, P. and S. Wood, with H.W. Hohn and T. Manwaring 1988 Recruitment and selection in the labour market Avebury, Aldershot.

Witz, A. 1986 Patriarchy and the labour market: occupational control strategies and the medical division of labour in D. Knights and H. Willmott (eds) Gender and the labour process Gower, Aldershot.

\section{Author}

Jane Higgins is a lecturer in the Sociology Department of the University of Canterbury. 